\title{
Leveraging Offshore IT Outsourcing by SMEs through Online Marketplaces
}

\author{
Uladzimir Radkevitch, Eric van Heck and Otto Koppius
}

\begin{tabular}{|l|l|}
\hline \multicolumn{2}{|l|}{ ERIM REPORT SERIES RESEARCH IN MANAGEMENT } \\
\hline ERIM Report Series reference number & ERS-2006-045-LIS \\
\hline Publication & August 2006 \\
\hline Number of pages & 23 pages \\
\hline Persistent paper URL & \\
\hline Email address corresponding author & uradkevitch@rsm.nl \\
\hline Address & Erasmus Research Institute of Management (ERIM) \\
& RSM Erasmus University / Erasmus School of Economics \\
& Erasmus Universiteit Rotterdam \\
& P.O.Box 1738 \\
& 3000 DR Rotterdam, The Netherlands \\
& Phone: $\quad+31104081182$ \\
& Fax: $\quad+31104089640$ \\
& Email: info@erim.eur.nl \\
& Internet: $\quad$ www.erim.eur.nl \\
\hline
\end{tabular}

Bibliographic data and classifications of all the ERIM reports are also available on the ERIM website: www.erim.eur.nl 


\section{ERASMUS RESEARCH INSTITUTE OF MANAGEMENT}

\section{REPORT SERIES \\ RESEARCH IN MANAGEMENT}

\begin{tabular}{|l|l|}
\hline ABSTRACT AND KEYWORDS \\
\hline Abstract & $\begin{array}{l}\text { Following their larger counterparts, an increasing number of small firms outsource their IT tasks } \\
\text { to lower cost offshore destinations. For small firms, however, offshore outsourcing is a difficult } \\
\text { undertaking as it involves high transaction costs. Online marketplaces for IT services, which } \\
\text { have recently become available to small firms, make offshore IT outsourcing more accessible } \\
\text { and manageable, although differences in the marketplace design result in varying outcomes } \\
\text { across the marketplaces. This has consequences for SME's decision as to which online } \\
\text { marketplace to use, because different markets may have different types of benefits and costs. } \\
\text { This paper sets to analyze some of the similarities and differences between online marketplaces } \\
\text { for IT services and their effects for small firms. First, we analyze if and how online marketplaces } \\
\text { reduce small firms' transaction costs in offshore IT outsourcing. Second, we examine the effects } \\
\text { of market entry barriers on outcomes of online marketplaces and their implications for small } \\
\text { firms. The results indicate that online marketplaces for IT services do reduce transaction costs } \\
\text { for small firms in offshore outsourcing across ten specific market processes. More surprising, } \\
\text { however, is the finding that the lower market entry barriers for suppliers result in lower prices for } \\
\text { buyers without compromising other aspects of market performance. }\end{array}$ \\
\hline Offshore IT Outsourcing, Online Market, Reverse Auction, Process-Stakeholder Analysis \\
\hline Free Keywords & $\begin{array}{l}\text { The ERIM Report Series is distributed through the following platforms: } \\
\text { Academic Repository at Erasmus University (DEAR), DEAR ERIM Series Portal } \\
\text { Social Science Research Network (SSRN), SSRN ERIM Series Webpage } \\
\text { Research Papers in Economics (REPEC), REPEC ERIM Series Webpage }\end{array}$ \\
\hline $\begin{array}{l}\text { The electronic versions of the papers in the ERIM report Series contain bibliographic metadata } \\
\text { by the following classification systems: } \\
\text { Library of Congress Classification, (LCC) } \underline{\text { LCC Webpage }} \\
\text { Journal of Economic Literature, (JEL), JEL Webpage } \\
\text { ACM Computing Classification System CCS Webpage } \\
\text { Inspec Classification scheme (ICS), ICS Webpage }\end{array}$ \\
\hline
\end{tabular}




\section{LEVERAGING OFFSHORE IT OUTSOURCING BY SMES}

\section{THROUGH ONLINE MARKETPLACES}

\author{
Uladzimir Radkevitch \\ Department of Decision and Information Sciences, RSM \\ Erasmus University \\ P.O. Box 1738, 3000 DR Rotterdam, the Netherlands \\ uradkevitch@rsm.nl
}

\section{Otto Koppius}

Department of Decision and Information Sciences, RSM Erasmus University

P.O. Box 1738, 3000 DR Rotterdam, the Netherlands

\author{
Eric van Heck \\ Department of Decision and Information Sciences, \\ RSM Erasmus University \\ P.O. Box 1738, 3000 DR Rotterdam, the Netherlands \\ evanheck@rsm.nl
}

\section{ABSTRACT}

Following their larger counterparts, an increasing number of small firms outsource their IT tasks to lower cost offshore destinations. For small firms, however, offshore outsourcing is a difficult undertaking as it involves high transaction costs. Online marketplaces for IT services, which have recently become available to small firms, make offshore IT outsourcing more accessible and manageable, although differences in the marketplace design result in varying outcomes across the marketplaces. This has consequences for SME's decision as to which online marketplace to use, because different markets may have different types of benefits and costs. This paper sets to analyze some of the similarities and differences between online marketplaces for IT services and their effects for small firms. First, we analyze if and how online marketplaces reduce small firms' transaction costs in offshore IT outsourcing. Second, we examine the effects of market entry barriers on outcomes of online marketplaces and their implications for small firms. The results indicate that online marketplaces for IT services do reduce transaction costs for small firms in offshore outsourcing across ten specific market processes. More surprising, however, is the finding that the lower market entry barriers for suppliers result in lower prices for buyers without compromising other aspects of market performance.

Keywords: offshore IT outsourcing, online market, reverse auction, process-stakeholder analysis. 


\section{INTRODUCTION}

Offshore outsourcing of IT services has become a large industry in India, Russia, Eastern Europe, China, and other regions of the world, employing hundreds of thousands of people and generating tens of billions dollars in turnover on a yearly basis (Carmel and Tija 2005). Although offshore IT outsourcing has gone mainstream, until recently large businesses were the only ones enjoying the lion's share of benefits from offshore IT outsourcing as well as the attention from the academic community in this respect.

Small and medium enterprises (SMEs) are a potential source of tremendous demand for offshore IT outsourcing services. European SMEs alone are predicted to spend USD 109 bln on IT investments in $2006^{1}$. Their demand for offshore IT outsourcing, however, remains to be realized! In comparison to their larger counterparts, SMEs face more difficulties with the access to IT resources due to factors, such as poorer access to financing (Dean, et al. 1998) and poorer in-house availability of dedicated high-skilled technical personnel (Nooteboom 1993). In offshore IT outsourcing SMEs face relatively high costs of contacting, contracting, and controlling suppliers than large firms (Carmel and Nicholson 2005).

For SMEs, the recent rise of online marketplaces for professional services came as a blessing. Online marketplaces facilitate SMEs' access to offshore resources by providing functionality for supplier search, projects allocation and execution. The leading online marketplaces with a strong focus on IT include Elance Online, Rent a Coder, and eWork. In the early 2006 Rent a Coder was facilitating over 12 thousand IT projects on a monthly basis while enjoying a $60 \%$ yearly growth (Radkevitch 2006). Elance Online has conducted transactions for over USD 90 million since the marketplace launched in $1999^{2}$.

\footnotetext{
${ }^{1}$ http://www.allbusiness.com/periodicals/article/441101-1.html

${ }^{2}$ www.elance.com
} 
These marketplaces typically support a similar range of core exchange functionality, such as catalogues of suppliers; project pricing and allocation by means of reverse auctions; settlement of payments; workspace; and supplier rating and feedback systems (Snir \& Hitt, 2003). The differences between the marketplaces are in more subtle design dimensions such as the level of market entry barriers or collaboration functionality. According to the electronic markets literature, aspects of market design account for differences in the success and outcomes of online marketplaces (Kambil and van Heck 1998, Koppius 2002). In particular, while having low market entry barriers is important to attract the critical mass of buyers and suppliers (Kambil and van Heck 2002), entry of low quality participants of both types results in a large proportion of potential deals being cancelled (Radkevitch, et al. 2006, Snir and Hitt 2003).

The objective of this paper is two-fold. First, this paper aims to analyze how online marketplaces for IT services facilitate SMEs' access to offshore IT resources. We look at ten distinct market processes of a leading online marketplace, and discuss their effect on buyer and supplier transaction costs through the facets of the process-stakeholder analysis framework developed by Kambil and van Heck (1998). Second, we consider differences in entry barriers of two leading online marketplaces, and empirically analyze their impact on market outcomes along three dimensions: the percentage of awarded projects, average project price, and average satisfaction with the supplier.

The rest of the paper is structured as follows. Section 2 provides a review of literature on offshore IT outsourcing, economics of small firms and their use of IT, and on online markets. In Section 3 we analyze the transaction cost reduction effects of online marketplaces. In Section 4 we elaborate on market entry barriers and formulate hypotheses relating entry barriers to market outcomes. Section 5 is dedicated to hypotheses testing and discussion of the results. Section 6 presents conclusions of the study. 


\section{LITERATURE REVIEW}

\subsection{Offshore IT outsourcing}

Offshore IT outsourcing is a complex business arrangement that reaches across national and cultural borders. Academic research on both "local" and offshore IT outsourcing centers on issues such as outsourcing decisions (Ang \& Straub, 1998; Poppo \& Zenger, 1998), managing relationships and processes with outsourcing partners (Feeny, et al. 2005, Rottman and Lacity 2006, Sabherwal 1999), and handling transaction costs and risks in outsourcing (Carmel and Tija 2005, Kliem 2004, Lee, et al. 2004).

IT outsourcing starts with a decision to outsource. Transaction costs defined by transaction attributes, such as asset specificity and measurement difficulty, and production efficiencies associated with outsourcing influence outsourcing decisions and degree of outsourcing (Ang and Straub 1998). When outsourcing goes offshore, criteria such as business environment, political risks, labor pool size, and costs need to be analyzed in the choice of offshore destination (Carmel and Tija 2005). A number of specific selection criteria, such as language skills, international experience global presence, and infrastructure have to be considered when selecting an offshore outsourcing provider, in addition to a general set of criteria such as costs, reputation, financial stability, processes, etc. (Carmel and Tija 2005).

Managing offshore outsourcing contracts once they are under way is even a more complex task. Costs of control make up the greatest portion of buyer's transaction costs. Due to micromanagement, transaction costs of US companies amount to $50 \%$ of offshore outsourcing contract volume, while they are only 5 to $10 \%$ when domestic outsourcing companies are involved (Rottman and Lacity 2006). Competitive bidding and ambiguity of the specifications of IT projects may result in outsourcing providers falling prey to winner's curse that can negatively affect performance of all parties involved (Kern, et al. 2002). The success of 
offshore outsourcing projects is also dependent on the relationships that develop between the parties, particularly on trust, cooperation and joint problem solving (Feeny, et al. 2005, Sabherwal 1999). These relationships are dynamic and can develop either through a virtuous or a vicious (distrust) cycle (Sabherwal, 1999), making proper control of the relationship of great importance.

\subsection{Economics of small firms and the use of IT}

Small firms received special treatment in the economic and managerial literature due to a number of properties that make them different from large firms. Small firms enjoy a number of advantages over their large counterparts, but also suffer from specific disadvantages. The advantages are of a behavioral nature, while the disadvantages are rooted in poorer availability of material resources (Nooteboom, 1993). Due to factors, such as the entrepreneurial drive, risk taking, motivation and perseverance, less bureaucracy, greater flexibility as well as proximity of management to the customer and to production, SMEs can be potentially successful in competition (Nooteboom, 1993). On the other hand, small firms generally face smaller economies of scale and scope, as well as inferior economies of experience and learning (Nooteboom, 1993).

Disadvantages of small firms can be best explained via the facets of transaction costs economics (TCE) that analyses transaction governance choices on the basis of underlying transaction costs (Williamson, 1975). Nooteboom (1993) analyzed the effect of firm’s size on the transaction costs along the dimensions of contact, contract, and control. By discussing the effects of the economies of scope, scale, experience, and learning, he showed that small firms bear higher costs to contact, contract, and control a transaction partner. Small firms appear to be less capable of making use of these economies due to bounded rationality, uncertainty, and asset specificity (Nooteboom, 1993). 
Small firms also face more difficulties with the IT resources due to poorer access to financial resources (Dean et al., 1998) and poorer in-house availability of dedicated high-skilled technical personnel (Nooteboom, 1993). Extending the work of Nooteboom, (Carmel and Nicholson 2005) showed that small firms are also less involved in offshore IT outsourcing due to relatively higher costs of contacting, contracting, and controlling offshore vendors. These costs encompass, correspondingly: 1) search costs (costs of marketing - in case of suppliers); 2) costs of drawing a contract, negotiating, and obtaining information on supplier reliability, etc.; and 3) costs of monitoring, dispute resolution, renegotiation, and arbitration, etc (Nooteboom, 1993).

In order to offset the impediments to offshore IT outsourcing, small firms can use a number of transaction cost reduction approaches such as liaison of knowledge flows, gaining experience, and providing control channels (from the supplier's side), etc (Carmel and Nicholson 2005). Carmel and Nicholson (2005) pointed out a significant role of the marketplace, which is implicitly defined as consisting of market actors including intermediaries and vendors, in the reduction of transaction costs. Vendors contribute to the transaction costs reduction by simplifying contracting, providing control channels, and standardizing services, while intermediaries provide expertise and knowledge on offshore outsourcing (Carmel and Nicholson 2005).

\subsection{Online markets for IT services}

Online market is defined as an interorganizational information system through which multiple buyers and sellers interact to accomplish one or more of the following market-making activities: identifying potential trading partners; selecting a specific partner, and executing the transaction (Choudhury, et al. 1998). Early literature on online marketplaces predicted that the reduction of coordination costs due to the introduction of IT would lead to a shift from hierarchy to market governance (Malone, et al. 1987), while decrease in search costs would 
result in higher allocation efficiency and lower prices (Bakos 1991). Later studies found that the outcomes of online markets are not necessarily better than those of traditional markets due to factors, such as differences in quality and transportation cost (Bailey, Peterson, \& Brorsen, 1991), and information available during the exchange (Koppius 2002).

Online markets for IT services became a focal point of research on market outcomes not long after the term "e-lance economy" was introduced by (Malone and Laubacher 1998) to label an economy largely based on temporary organizations of individuals that emerge and dissolve when business opportunities arise and disappear, and where IT serves to link individual nodes (Malone, Yates \& Benjamin, 1987).

While IT decreases the coordination costs of the linking mechanism (most often a market-based mechanism) (Malone, Yates \& Benjamin, 1987), the costs faced by supplier and buyers of placing and evaluating a bid respectively, will not go to zero. In one of the first such studies the effect of costly bidding and bid evaluation at reverse auctions at online marketplace for IT services was examined by Snir and Hitt (2003), who found that more expensive projects tend to attract on average lower quality suppliers, resulting in buyers often withdrawing from auctions without awarding their contracts to suppliers. Moreover, when an auction attracts too few bids it becomes uneconomical for the buyer to perform evaluation and award her contract either (Carr 2003). Opportunistic behavior of buyers, who use online marketplaces for comparison shopping or look for free consultations from suppliers, was identified as another reason for not awarding contracts (Radkevitch, et al. 2006).

Finally, market design also accounts for a variation in the outcomes of online marketplaces. The way the market processes are embodied by the functionality of online markets, also affects benefits and costs for buyers, suppliers and market makers, eventually resulting in marketplace success or failure (Kambil and van Heck 2002). Market processes left aside, what type of 
information is made available to whom during the market process also impacts outcomes of the market (Koppius 2002).

\section{ONLINE MARKETS' EFFECTS ON TRANSACTION COSTS OF SMES IN OFFSHORE IT OUTSOURCING}

According to (Nooteboom, 1993), one of the factors accounting for SMEs' relatively higher transaction costs is that their rationality is "more bounded", which results from their inferior capacities of information processing as well as from poorer availability of specialized personnel. To compensate for this type of bounded rationality, SMEs might buy in the necessary expertise (e.g. in procurement, IT, and finance, etc.), which, however, involves additional transactional costs (Nooteboom, 1993). Nooteboom (1993) also predicts a trend toward trilateral governance in transactions with small firms, where a third party would exercise functions of control and arbitration. Finally, he suggests applying collective or institutional efforts to mitigate transaction or governance costs by restricting opportunistic behavior and uncertainty (Nooteboom, 1993).

Online marketplaces help SMEs overcome their specific disadvantage quite in line with the directions outlined above. In principle, online marketplaces can enable smarter buying by providing SMEs with advice, standardized processes, and reference projects; they take on the transaction governance role by setting exchange rules and assuming the arbitration function; they provide rating and feedback tools that help distinguish reliable and reputable participants from lower quality participants and potential opportunists.

Table 1. Leading online marketplaces for IT services

\begin{tabular}{|c|c|c|c|c|c|}
\hline $\begin{array}{l}\text { Marketplace } \\
\text { (year } \\
\text { launched) }\end{array}$ & Scope & Key Features & Participation & $\begin{array}{l}\text { Entry for } \\
\text { suppliers }\end{array}$ & $\begin{array}{l}\text { Business } \\
\text { Model }\end{array}$ \\
\hline $\begin{array}{l}\text { Elance Online } \\
\text { (1999) }\end{array}$ & $\begin{array}{l}\text { Professional } \\
\text { services }\end{array}$ & $\begin{array}{l}\text { Catalogue of suppliers; reverse } \\
\text { auctions; invoice management and } \\
\text { payments; project management; } \\
\text { rating and feedback system. }\end{array}$ & $\begin{array}{l}\text { Over } 1.000 \\
\text { open projects } \\
\text { simultaneously }\end{array}$ & $\begin{array}{l}\text { Free and fee- } \\
\text { based } \\
\text { membership }\end{array}$ & $\begin{array}{l}\text { Supplier } \\
\text { funded }\end{array}$ \\
\hline eWork (1999) & $\begin{array}{l}\text { Professional } \\
\text { services }\end{array}$ & $\begin{array}{l}\text { Suppliers and projects screening; } \\
\text { catalogue of suppliers; reverse }\end{array}$ & No data & $\begin{array}{l}\text { Suppliers pay } \\
\text { an entry fee }\end{array}$ & $\begin{array}{l}\text { Supplier } \\
\text { funded }\end{array}$ \\
\hline
\end{tabular}


auctions; invoice management and payments; project management; rating and feedback system.

\begin{tabular}{|c|c|c|}
\hline $\begin{array}{l}\text { Rent-a-coder } \\
(2001)\end{array}$ & $\begin{array}{l}\text { IT and related } \\
\text { services }\end{array}$ & $\begin{array}{l}\text { Catalogue of suppliers; reverse } \\
\text { auctions; invoice management and } \\
\text { payments; escrow accounts; } \\
\text { project management; rating and } \\
\text { feedback system. }\end{array}$ \\
\hline $\begin{array}{l}\text { Guru.com } \\
(2000)\end{array}$ & $\begin{array}{l}\text { Professional } \\
\text { services }\end{array}$ & $\begin{array}{l}\text { Catalogue of suppliers; reverse } \\
\text { auctions; invoice management and } \\
\text { payments; escrow accounts; } \\
\text { project management; rating and } \\
\text { feedback system. }\end{array}$ \\
\hline $\begin{array}{l}\text { criptlance } \\
\text { 001) }\end{array}$ & $\begin{array}{l}\text { IT and related } \\
\text { services }\end{array}$ & $\begin{array}{l}\text { Catalogue of suppliers; reverse } \\
\text { auctions; invoice management and } \\
\text { payments; escrow accounts; } \\
\text { project management; rating and } \\
\text { feedback system. }\end{array}$ \\
\hline $\begin{array}{l}\text { GetACoder } \\
(2004)\end{array}$ & $\begin{array}{l}\text { IT and related } \\
\text { services }\end{array}$ & $\begin{array}{l}\text { Catalogue of suppliers; reverse } \\
\text { auctions; invoice management and } \\
\text { payments; escrow accounts; } \\
\text { project management; rating and } \\
\text { feedback system. }\end{array}$ \\
\hline Desk (2004) & $\begin{array}{l}\text { Freelance } \\
\text { staffing }\end{array}$ & $\begin{array}{l}\text { Supplier screening; Catalogue of } \\
\text { suppliers; reverse auctions; invoice } \\
\text { management and payments; project } \\
\text { management; bug tracking; online } \\
\text { supplier monitoring; daily status } \\
\text { reports; activity log; code version } \\
\text { control; rating and feedback } \\
\text { system. }\end{array}$ \\
\hline
\end{tabular}

\begin{tabular}{|c|c|c|}
\hline & $\begin{array}{l}\text { and are } \\
\text { screened by } \\
\text { the } \\
\text { marketplace }\end{array}$ & \\
\hline $\begin{array}{l}\text { Over } 12.000 \\
\text { projects } \\
\text { executed per } \\
\text { month }\end{array}$ & Free & $\begin{array}{l}\text { Supplier } \\
\text { funded }\end{array}$ \\
\hline $\begin{array}{l}6.300 \text { posted } \\
\text { projects per } \\
\text { month }\end{array}$ & $\begin{array}{l}\text { Free and fee- } \\
\text { based } \\
\text { membership } \\
\text { types are } \\
\text { possible }\end{array}$ & $\begin{array}{l}\text { Supplier } \\
\text { funded }\end{array}$ \\
\hline $\begin{array}{l}1125 \text { projects } \\
\text { open (accessed } \\
28.06 .06 \text { ) }\end{array}$ & Free & $\begin{array}{l}\text { Supplier } \\
\text { funded }\end{array}$ \\
\hline $\begin{array}{l}1725 \text { projects } \\
\text { posted during } \\
30 \text { last days } \\
\text { (accessed } \\
28.06 .06 \text { ) }\end{array}$ & Free & $\begin{array}{l}\text { Supplier } \\
\text { funded }\end{array}$ \\
\hline $\begin{array}{l}500+\text { projects } \\
\text { open }\end{array}$ & $\begin{array}{l}\text { Suppliers } \\
\text { screened by } \\
\text { the } \\
\text { marketplace }\end{array}$ & $\begin{array}{l}\text { Buyer } \\
\text { funded }\end{array}$ \\
\hline
\end{tabular}


assign a rating to the supplier and provide a feedback on supplier's performance. In the analysis of market processes below we provide more details on how these marketplaces function.

The hypotheses to be tested in subsequent section are as follows:

Hypothesis 1a: Online marketplaces for IT services reduce costs of contact for small companies in offshore IT outsourcing.

Hypothesis 1b: Online marketplaces for IT services reduce costs of contract for small companies in offshore IT outsourcing.

Hypothesis 1c: Online marketplaces for IT services reduce costs of control for small companies in offshore IT outsourcing.

\section{EMPIRICAL ANALYSIS PART 1}

The effects of online marketplaces on the transaction costs of SMEs in offshore IT outsourcing are analyzed with the help of process-stakeholder analysis framework, developed by Kambil et al., 1998, to evaluate online marketplace adoption. The conventional way to apply the processstakeholder analysis framework is to analyze ten market processes of a specific online marketplace, and their effects on buyers, suppliers, and market makers. These ten processes are product representation, regulation, risk management, influence, dispute resolution, search, pricing, logistics (which we term "service delivery" here), payment and settlement, and authentication (Kambil and van Heck 1998). The analysis identifies the net benefit or loss that each type of stakeholders incurs from participation in the marketplace, which explains marketplace adoption success or failure.

In this study we apply the process-stakeholder analysis framework in a slightly different way, by analyzing the different market processes with regard to their effect on transaction costs of SMEs in offshore IT outsourcing. Since the framework has some of its roots in the transaction costs theory we believe it to be appropriate to map it on three types of transaction costs - costs 
of contact, contract, and control - used by (Nooteboom, 1993) to analyses SMEs' disadvantages in comparison to large firms.

On the empirical side, the analysis is based on a leading marketplace for IT service, Rent A Coder. Rent A Coder was founded in 2001 and focuses on IT and related services. In the early 2006 the marketplace was facilitating over 12 thousand IT projects on a monthly basis while enjoying a 60\% yearly growth (Radkevitch, 2006). The ten market processes at Rent A Coder are organized as follows:

Search. Rent A Coder maintains a searchable (by skills, country, and other attributes) catalogue of suppliers. Supplier profiles contain detailed information on their skills, experience, and past projects.

Pricing. Three match-making and pricing mechanisms are available for buyers - open reverse auction, private auction and one-to-one project. Request for proposals posted via reverse auctions are available for bids to all registered suppliers, while private auctions involve only invited suppliers. One-to-one projects are for suppliers with who the buyer has worked previously. The requests for proposals contain project description, requirements for the deliverables, budget estimation and indication of a deadline. Supplier's bids contain bid amount and text description. Supplementary files such as detailed proposals, mock-ups, and examples of code can be attached to the bid.

Logistics (service delivery). Rent A Coder provides functionality to exchange comments and files via a message board. Source code and other types of deliverables (e.g. elements of web design, programmes, etc) can also be delivered this way.

Payment and settlement. Payments can be managed via internal payment system; money is held at the account before the work is accomplished. A number of payment options are available, including PayPal, mail checks, and bank wire transfer, etc. This flexibility is important when buyer and supplier come from different countries. 
Authentication. Buyers and suppliers can rate one another and provide performance feedbacks, which forms their reputation at the online marketplace.

Product representation. Detailed supplier profiles are available at the marketplace. Supplier's qualification can be certified by a third party organization “Expert Rating”. Buyers’ feedback and ratings for previous projects in aggregated and detailed form are directly available in the supplier’s profile.

Regulation. Participation at the marketplace for buyers and supplier is subject to Terms and Conditions, and Custom Software Seller Agreement. Issues such as communications between buyer and supplier, payments, use of $3^{\text {rd }}$ party code are subject to these regulations. Users violating the rules might be expelled from the marketplace.

Risk management. Escrow accounts, buyer /supplier rating, and feedback system as well as $3^{\text {rd }}$ party certification of suppliers' skills contribute to establishing trust at the marketplace.

Influence. Escrow accounts, buyer /supplier rating, and feedback system as well as $3^{\text {rd }}$ party certification of suppliers’ skills contribute to establishing trust at the marketplace.

Dispute resolution. Arbitration procedure is available for buyers and suppliers in case there are disputes that cannot be resolved by other means. Internal investigation team performs the arbitration.

The analysis is summarized in Table 2. Column Process identifies a market process, column Description provides a brief description of the process and columns Effect on buyers and Effect on suppliers specify the effect of the market process on transaction costs of the respective stakeholder (compared to a situation when an SME would embark on offshore outsourcing on its own, i.e. without relying on an online marketplace).

Table 2. Analysis of the effects of online marketplace processes on buyers' and suppliers' transaction costs

Process

Search

\section{Impact in offshore IT} outsourcing

Details on supplies from dozens of countries are available in a searchable database in an easy to compare format.
Effect on buyers

Reduces contact costs (e.g. by comparison to search via yellow pages, etc.).
Effect on suppliers

Reduces contact costs (e.g. in comparison to participating in IT fairs, or direct marketing). 
Pricing

Logistics
delivery)

Authentication

Product representation

Regulation

Risk management

Influence

Dispute resolution

Net Effect
Suppliers bid at reverse auctions or negotiate privately with buyers. Parties benefit from standardized project allocation procedures.

(service Parties benefit from the availability of a file delivery and repository functionality.

and Payments can be managed via internal payment system with multiple payment options.

Supplier/ buyer rating and feedback system provide grounds for trust that would otherwise be difficult to establish in a cross-border setting.

Availability of standardized supplier profiles provides an easy way to assess and compare suppliers.

A standard and strict marketplace policy provides independence from national legislations in drawing contracts and solving disputes.

Creates a common reference framework and trust that is hard to build in an offshore setting.

Dedicated team enforces marketplace policies. Users violating the rules may be expelled from the marketplace.

Availability of a standard and strict marketplace policy provides independence from national legislations in solving disputes.
Reduces contact costs

(suppliers volunteer to

bid) and contract costs (in comparison to bilateral negotiations).

Reduces control costs

Reduces control costs

Reduces control costs by providing information on provider quality and thus enabling selection of higher quality providers.

\section{Reduces contract costs}

Reduced contract and control costs

Reduces control costs

Reduces control costs

Reduces control costs

Reduces control costs

Reduces control costs

Reduces control costs

Positive
Reduces contact and contract costs

Reduces control costs

Reduces contact (less need to verify buyer trustworthiness) and control costs (partners are less likely to behave opportunistically).

Reduces contact costs

Reduced contract and control costs
Reduces control costs

As shown in Table 2, all ten market processes at Rent A Coder contribute to the reduction of transaction costs for buyers and suppliers of IT outsourcing services. Hypotheses 1a, $1 \mathrm{~b}$ and 1c have been confirmed. These three effects amount to an overall positive effect that online marketplaces bring about for SMEs, as indicated in Table 2.

In summary, online marketplaces thus cater for the needs of SMEs by providing them with standardized processes and tools of contacting, contracting, and controlling offshore suppliers of IT services. This partially compensates for the lack of expertise that SMEs generally face when it comes to sourcing and evaluating offshore suppliers, and it also provides $3^{\text {rd }}$ party 
governance of the transactions. In addition, online marketplaces may provide a basis for the emergence of institutional trust, thus further reducing opportunism and transaction costs.

The ten market processes described an the example of Rent A Coder to a large extent represent generic functionality that is common to all online marketplaces as can be seen from Table 1 . Therefore, we suggest that the findings of the analysis can be generalized to the majority of online marketplaces for IT services. Differences in the design of these marketplaces, such as entry barriers or collaboration functionality, are not crucial for the present analysis. However, one of them, namely market entry barriers, is a focus of the following section.

\section{ENTRY BARRIES AND THEIR IMPLICATIONS FOR MARKET OUTCOMES}

Achieving a critical mass of users is a key factor for online marketplace survival and success (Kambil and van Heck 2002). In the case of online markets for IT services, the critical mass on both buyers’ and suppliers' side is important. Buyers need enough suppliers to fuel competitive bidding at reverse auctions. Suppliers, in their turn, require sufficient amount of opportunities to bid on and occasionally win.

However, low entry barriers allow less informed, less professional or lower quality participants to access the marketplace, which results in decreasing quality of information exchange (Gu and Hitt 2001) and other inefficiencies. Considering the effects of costly bidding and bid evaluation on the behavior of buyers and suppliers, Snir and Hitt (2003) found that due to the costs of bidding for IT projects, low quality suppliers are more likely to bid for high-value projects with a higher expected pay-off. The rising costs of bid evaluation, consequently, result in a situation when it becomes uneconomical for a buyer to perform bid evaluation (Snir \& Hitt, 2003). The buyer may choose to withdraw from the auction without awarding her project to a supplier. 
On the other hand, low entry barriers for buyers facilitate market access for those who do not intend to award and execute their projects within the marketplace. Instead, such buyers do comparison shopping or look for free consultations from bidders. Again, the result is a relatively low level of awarded projects (Radkevitch, et al. 2006).

In this study we focus on entry barriers for suppliers, which exist in two forms - entry fees and supplier screening by the marketplace. For instance, at Elance Online suppliers are required to pay monthly fee that varies per service package and project category, e.g. USD 295/month for Software and Technology category and USD 75 for Writing and Translation category. At Rent a Coder, by contrast, no subscription fees are required. Besides, suppliers, applying for "Select" status in Elance Online (which provides more marketing and bidding options than other subscription types), are screened by the marketplace staff before bidding for projects is allowed. Below we formulate hypotheses on the effects of entry barriers for suppliers on the market outcomes across three dimensions - project award rate, project value, and buyer satisfaction.

Project award rate is the percentage of buyer's requests posted through an open reverse auction that ends up by buyer's selecting one of several auction winners. In practice, however, less than $40 \%$ of open auctions result in allocated projects (Radkevitch, et al. 2006, Snir and Hitt 2003). Lower market entry barriers for suppliers enable lower quality suppliers an easier access to the marketplace, as at least some of these suppliers would otherwise abstain from investing into accessing the market, anticipating a negative pay-off. Following the argument by Snir and Hitt (2003), who found that extensive bidding by lower quality suppliers may lead to buyer's withdrawal from the action, we hypothesize that lower market entry barriers lead to a lower project award rate.

Hypothesis 2. Project award rate will be lower at an online marketplace with lower entry barriers for suppliers. 
Buyer satisfaction. Satisfaction with the performance is often used as a proxy for business performance (Ganesan 1994, Poppo and Zenger 1998). By measuring and comparing buyer satisfaction across projects it must be possible to indirectly evaluate performance in projects across an online marketplace. We hypothesize that even if an auction ends up with a project award, performing a project with a lower quality supplier may lead to higher costs for the buyer due to higher control costs and higher probability of supplier’s opportunism.

Hypothesis 3. Satisfaction with suppliers will be lower at an online marketplace with lower entry barriers for suppliers.

Project value. Low market entry barriers are likely to result in low bids for a number of reasons, among which are higher competition among suppliers; lower production costs in suppliers' value function due to lesser investments in quality; and higher probability of opportunistic bidding due to less reputation at stake. Therefore, our final hypothesis is as follows:

Hypothesis 4. Value of awarded projects will be lower at an online marketplace with lower entry barriers for suppliers.

\section{EMPIRICAL ANALYSIS PART 2}

\subsection{Data}

The empirical data for the analysis were obtained from two leading online marketplaces for IT services. Marketplace 1 was established in 1998 and encompasses a wide variety of professional services, from tax consulting to language translation and from creative writing to data entry. IT services, such as application development, web design and development, and database development represent the most substantial part of the marketplace's activity. Marketplace 2 was founded in 2001 and focused on IT services, with the range of IT services similar to that of Marketplace 1. 
In order to minimize the possibility for project heterogeneity to interfere into the causal logic, we focus on one subgroup of IT services for testing our hypotheses. Thus the homogeneity of projects from the different online marketplaces is ensured. We chose to focus on the subgroup that is labeled "Database Development" at Marketplace 1 and "Database" at Marketplace 2. These categories seem to allow for a more rigorous comparison between the projects from the different marketplaces than such subcategories as, for instance, Application development at Marketplace 1 and Computer Platforms at Marketplace 2. The projects in "Database Development” subgroup at Marketplace 1 were posted between January 26, 2005 and August 6, 2005. The data on projects in "Database" subgroup at Marketplace 2 covers the period from January 1, 2006 to July 7, 2006.

\subsection{Hypotheses testing and discussion}

We operationalize the relative level of market entry barriers for suppliers via the membership fee. Suppliers at Marketplace 1 do pay a membership fee that varies depending on the service package (in the case of Database Development sub-category it is USD 245/month), while suppliers at Marketplace 2 do not pay an entry fee. Therefore, entry barriers for suppliers at Marketplace 1 are higher than Marketplace 2.

While measuring the percentage of project awards is straightforward, the two other market outcomes, buyer satisfaction and average project value, need to be operationalized.

Project value is operationalized through average bid, as in (Radkevitch et al., 2006; Snir et al., 2003). Buyer's satisfaction with supplier's performance is operationalized though the rating value assigned to supplier for a given project. Although detailed rating is available for a number of performance dimensions (Quality, Response, Professionalism, Expertise, Cost, and Schedule) at Marketplace 1 we use averaged rating for a more straightforward comparison between the marketplaces. 
Besides, the rating scales at Marketplace 1 and Marketplace 2 are different. In the first case the rating can take values from 1 to 5 and in the second case from 1 to 10 . We multiplied satisfaction values from Marketplace 1 by 2, in order to be able to make comparison. Descriptive statistics for the data is presented in Table 3.

Table 3. Descriptive Statistics

Satisfaction

(Marketplace 2)

Satisfaction

(Marketplace 1)

Average bid

(Marketplace 2)

Average bid

(Marketplace 2)

\section{$\mathbf{N}$}

1521

66

2175

141
Minimum

1.00

1.10

4.00

75.00
Maximum

10.00

5.00

9404

8357
Mean

9.76

4.838

322.43

762.71
Std. Deviation

1.2786

.5832

680.84

1280.20

We applied different statistical tests to test out hypotheses, depending on the properties of the underlying data. The results are presented in Table 4. As can be seen from the test results in

Table 4, Hypotheses 2 and 3 rejected, while Hypothesis 4 is confirmed.

Table 4. Hypotheses testing

\begin{tabular}{|c|c|c|c|c|}
\hline & & alue & & \\
\hline & Market. 2 & Market. 1 & Test & Marketplace 2 \\
\hline Hypothesis 2. & $33.48 \%$ & $34.96 \%$ & Binomial test & 4.538 projects posted in \\
\hline Project award rate. & & & $\begin{array}{l}\text { Asymp. Sig. }(1- \\
\text { tailed })=0.268\end{array}$ & $\begin{array}{l}\text { Database category between } \\
\text { Jan } 12006 \text { and July 7, } 2006 \\
\text { in Database category. }\end{array}$ \\
\hline Hypothesis 3. & 9.76 & 9.66 & Mann-Whitney & 1.521 awarded and rated \\
\hline Buyer's & (out of 10 ) & (4.83 out of & $\mathrm{U}=17345$ & projects in Database category \\
\hline satisfaction. & & 5) & $\begin{array}{r}\mathrm{Z}=-17.20 \\
\text { Asymp. Sig. (2- } \\
\text { tailed) }=0.00\end{array}$ & $\begin{array}{l}\text { between Jan } 12006 \text { and July } \\
\text { 7, } 2006 \text { in Database category. }\end{array}$ \\
\hline $\begin{array}{l}\text { Hypothesis } 4 . \\
\text { Project value } \\
\text { (average bid). }\end{array}$ & USD 322.4 & USD 756.8 & Sig. $=0.000$ & $\begin{array}{l}2.175 \text { awarded projects in } \\
\text { Database category between } \\
\text { Jan } 12006 \text { and July 7, } 2006 \\
\text { in Database category. }\end{array}$ \\
\hline
\end{tabular}

\section{Data}

Marketplace 1

409 projects posted in Database Development category between January 26, 2005 and August 6, 2005. 66 awarded and rated projects in Database Development category posted between 26 , 2005 and August 6, 2005.

143 awarded projects in Database Development category posted between 26 , 2005 and August 6, 2005.

Hypothesis 1 was formulated as follows: project award rate will be lower at an online marketplace with lower entry barriers for suppliers. We applied binomial test to find out whether the proportion of project awards at Marketplace 1 (34.96\%) was significantly different from a benchmark. proportion, which in this case was the proportion of project awards at Marketplace 2 (33.48\%). The outcome of the test indicates that the difference between the 
means is not significant $(0.268)$. It can be argued that the test results lacked significance because of the small size of the project sample from Marketplace 1; with a larger sample the difference between the proportions of awarded projects at both marketplaces could have been significant. However, even in that case the support for the Hypothesis 2 would not be very persuasive and an explanation for that is required. One possible explanation can be that despite the fact that lower market entry barriers allow for the entry of lower quality suppliers, there is a sufficient number of high quality suppliers at both marketplaces, whose good performance over a number of projects has been certified via the rating and feedback system. Therefore, the fact that there might be lower quality suppliers at Marketplace 2 does not affect the award rate as there are a sufficient number of higher quality suppliers for a buyer to choose from.

Hypothesis 2 was formulated as follows: Satisfaction with suppliers will be lower at an online marketplace with lower entry barriers for suppliers. This hypothesis was not only rejected in its original form, but it appears that the average satisfaction at Marketplace 2 is marginally but significantly higher than at Marketplace 1. Remarkably, the average ratings (9.59 out of 10 and 4.83 out of 5) both are extremely close to the highest limit of respective rating scale. A possible explanation for such a distribution of rating values may be that the rating systems are used by the buyers primarily to reward suppliers for good performance and to punish for bad performance rather than for objective performance evaluation. This explains a very high proportion of the highest project ratings - 89\% of ratings at Marketplace 1 and $94 \%$ at Marketplace 2.

Hypothesis 3 was formulated as follows: Value of awarded projects will be lower at an online marketplace with lower entry barriers for suppliers. This hypothesis has been confirmed. Moreover, average price for database-related projects at Marketplace 1 (USD 756.8) appeared to be almost two and a half times higher than at Marketplace 2 (USD 322.4). Such a considerable difference might be explained by a) higher competition between suppliers at 
Marketplace 2, triggered by lower entry barriers and easier access to the marketplace; b) by lower quality and more probably opportunistic behavior of suppliers at Marketplace 2; c) suppliers at Marketplace 2 do not need to compensate for entry fees (suppliers at Marketplace 1 pay up to USD 245 in monthly membership fee to be able to place bids for projects in Database Development category).

\section{CONCLUSIONS}

This paper looked at the similarities and differences among online marketplaces for IT services and their effects for SMEs engaging in offshore IT outsourcing. The contribution of this paper is two-fold. First, we analyzed how online marketplaces for IT services affect transaction costs of contacting, contracting, and controlling of SMEs in offshore IT outsourcing. Ten market processes were scrutinized along the lines of the process-stakeholder analysis framework (Kambil and van Heck 1998). We conclude that the effect of these processes (product representation, regulation, risk management, influence, dispute resolution, search, pricing, logistics (service delivery), payment and settlement, and authentication) is to reduce transaction costs of offshore outsourcing, thereby enabling SMEs to enjoy the relevant advantages (low costs, flexibility, access to a wide pool of resources) - a luxury previously available only to large companies.

Second, while online marketplaces make the access to offshore resources easier, differences in market design lead to different market outcomes. We focused on the market entry barriers for suppliers, and their effects on the market outcomes. Datasets from two leading online marketplaces were used for the empirical analysis. Hypotheses testing showed that supplier entry conditions make a significant difference for the value of projects performed at a marketplace. No impact on the rate of project awards was found. Buyer satisfaction with the supplier performance was marginally but significantly higher at the marketplace with lower entry barriers. 
When analyzed together, the results of the second part of our investigation lead to an interesting conclusion. Contrary to the expectations, lower market entry barriers for supplier do not lead to worse market outcomes from an offshore outsourcing buyer perspective, as the proportion of awarded projects is not significantly different and the level of buyer's satisfaction with supplier performance is marginally higher in the case of lower entry barriers. At the same time, buyers face lower prices for projects in similar categories (in our case - Database Development at Marketplace 1 and Database at Marketplace 2). Put differently, lower market entry barriers result in lower prices for buyers without compromising other aspects of market performance. A possible explanation for this counter-intuitive finding is that online marketplaces for IT services have an effective reputation mechanism in place that compensates for lower average quality of new entrants by allowing a differentiation of suppliers by the quality of performance in accomplished projects.

Our findings have a number of limitations. First, more robust results could have been obtained through the comparative analysis of other similar categories of the two marketplaces, not just Database and Database Development. Second, the arguments could have been made stronger if the reliable measures of project complexity at different marketplace would have been available, as project complexity can be another factor influencing project value (Bajari, et al. 2003). Third, an inquiry into the composition of the supplier pool at different marketplaces may provide a better idea of supplier quality.

\section{LITERATURE}

1. Ang, S. and D.W. Straub, "Production and transaction economies and IS outsourcing: a study of the US banking industry,," MIS Quarterly, 22, 2 (1998),

2. Bajari, Patrick, Robert McMillan and Steven Tadelis, "Auctions versus Negotiations in Procurement: An Empirical Analysis. NBER Working Paper No. w9757.," (2003),

3. Bakos, J.Y., "A strategic analysis of electronic marketplaces," MIS Quarterly, 15, 3 (1991), 295-310.

4. Carmel, E. and B. Nicholson, "Small Firms and Offshore Software Outsourcing: High Transaction Costs and their Mitigation," Journal of Global Information Management, 13, 3 (2005), 
5. Carmel, E. and P. Tija, Offshoring Information Technology, 2005.

6. Carr, S.M., "Note on online auctions with costly bid evaluation," Management Science, 49, 11 (2003), 1521-1528.

7. Choudhury, V., K. S. Hartzel and B. R. Konsynski, "Uses and Consequences of Electronic Markets: An Empirical Investigation in the Aircraft Parts Industry," MIS Quarterly, (1998), 471-507.

8. Dean, T., R. Brown and C. Bamford, "Differences in large and small firm responses to

9. environmental context: strategic implications from a comparative analysis of business

10. formations," Strategic Management Journal, 19, 8 (1998), 709-728.

11. Feeny, D., M. Lacity and L. Willcocks, "Taking the measure of outsourcing providers," Sloan management review, 46, 3 (2005),

12. Ganesan, S., "Determinants of Long-term Orientation in Buyer-Supplier Relationships," Journal of Marketing, 58, (1994), 1-19.

13. Gu, B. and L.M. Hitt, "Transaction Costs and Market Efficiency," (2001), 85-96.

14. Kambil, A. and E. van Heck, "Re-engineering the Dutch Flower Auctions: A Framework for Analyzing Exchange Organizations," Information Systems Research, 9, 1 (1998), 1-19.

15. Kambil, A. and E. van Heck, Making Markets - How Firms Can Design and Profit from Online Auctions and Exchanges, Harvard Business School Press, Boston, Mass., 2002.

16. Kern, Thomas, Leslie P. Willcocks and Eric van Heck, "The Winner's Curse in IT Outsourcing: Strategies for Avoiding Relational Trauma," California Management Review, 44, 2 (2002), 47-69.

17. Kliem, Ralph, "Managing The Risks Of Offshore It Development Projects," Information Systems Management, Summer, (2004), 22-27.

18. Koppius, O., "Information Architecture and Electronic Market Performance. ERIM PhD. Series in Management no. 13," (2002),

19. Lee, J.N. , S.M. Miranda and Y. Kim, "IT Outsourcing Strategies: Universalistic, Contingency, and Configurational Explanations of Success," Information Systems Research, 15, 2 (2004), 110-131.

20. Malone, T. , J. Yates and R. Benjamin, "Electronic markets and electronic hierarchies: effects of information technology on market structure and corporate strategies," Communications of the ACM, 30, 6 (1987), pp. 484-497.

21. Malone, Thomas W. and Robert J. Laubacher, "The dawn of the e-lance economy," Harvard Business Review, 76, 5 (1998), 144-152.

22. Nooteboom, B., "Firm size effects on transaction costs," Small Business Economics, 5, (1993), 283-295.

23. Poppo, L. and T. Zenger, "Testing alternative theories of the firm: transaction cost, knowledge-based, and measurement explanations for make-or-buy decisions in information services," Strategic Management Journal, 19, (1998), 853-877.

24. Radkevitch, U., "The Romanian IT Outsourcing Industry: A Stable Stable of Freelancers for the Online Marketplaces," Outsourcing Journal, June, (2006),

25. Radkevitch, U., E. van Heck and O.R. Koppius, "Buyer commitment and opportunism in an electronic market for IT services," Rotterdam, (2006),

26. Rottman, J. and M. Lacity, "Proven Practices for Effectively Offshoring IT Work," Sloan Management Review, 47, 3, Spring (2006), 56-63.

27. Sabherwal, R., "The Role of Trust in Managing Outsourced IS Development Projects," Communications of the ACM, 42, 2 (1999), 80-87. 
28. Snir, Eli M and Lorin M Hitt, "Costly bidding in online markets for IT services," Management Science, 49, 11 (2003), 1504. 


\section{Publications in the Report Series Research ${ }^{*}$ in Management}

\section{ERIM Research Program: "Business Processes, Logistics and Information Systems"}

2006

Smart Business Networks Design and Business Genetics

L-F Pau

ERS-2006-002-LIS

http://hdl.handle.net/1765/7319

Designing and Evaluating Sustainable Logistics Networks

J. Quariguasi Frota Neto, J.M. Bloemhof-Ruwaard, J.A.E.E. van Nunen and H.W.G.M. van Heck ERS-2006-003-LIS

http://hdl.handle.net/1765/7320

Design and Control of Warehouse Order Picking: a literature review

René de Koster, Tho Le-Duc and Kees Jan Roodbergen

ERS-2006-005-LIS

http://hdl.handle.net/1765/7322

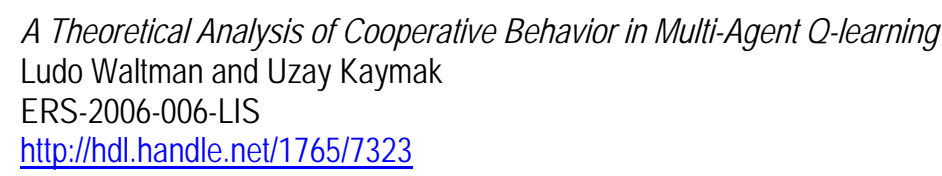

Supply-Chain Culture Clashes in Europe. Pitfalls in Japanese Service Operations M.B.M. de Koster and M. Shinohara

ERS-2006-007-LIS

http://hdl.handle.net/1765/7330

From Discrete-Time Models to Continuous-Time, Asynchronous Models of Financial Markets Katalin Boer, Uzay Kaymak and Jaap Spiering

ERS-2006-009-LIS

http://hdl.handle.net/1765/7546

Mobile Payments in the Netherlands: Adoption Bottlenecks and Opportunities, or... Throw Out Your Wallets Farhat Shaista Waris, Fatma Maqsoom Mubarik and L-F Pau

ERS-2006-012-LIS

http://hdl.handle.net/1765/7593

Hybrid Meta-Heuristics for Robust Scheduling M. Surico, U. Kaymak, D. Naso and R. Dekker ERS-2006-018-LIS

http://hdl.handle.net/1765/7644

VOS: A New Method for Visualizing Similarities between Objects

Nees Jan van Eck and Ludo Waltman

ERS-2006-020-LIS

http://hdl.handle.net/1765/7654

On Noncooperative Games, Minimax Theorems and Equilibrium Problems

J.B.G. Frenk and G. Kassay

ERS-2006-022-LIS

http://hdl.handle.net/1765/7809 
An Integrated Approach to Single-Leg Airline Revenue Management: The Role of Robust Optimization S. Ilker Birbil, J.B.G. Frenk, Joaquim A.S. Gromicho and Shuzhong Zhang

ERS-2006-023-LIS

http://hdll.handle.net/1765/7808

Optimal Storage Rack Design for a 3D Compact AS/RS with Full Turnover-Based Storage

Yu Yugang and M.B.M. de Koster

ERS-2006-026-LIS

http://hdll.handle.net/1765/7831

Optimal Storage Rack Design for a 3-dimensional Compact AS/RS

Tho Le-Duc, M.B.M. de Koster and Yu Yugang

ERS-2006-027-LIS

http://hdl.handle.net/1765/7839

E-Fulfillment and Multi-Channel Distribution - A Review

Niels Agatz, Moritz Fleischmann and Jo van Nunen

ERS-2006-042-LIS

Leveraging Offshore IT Outsoutcing by SMEs through Online Marketplaces

Uladzimir Radkevitch, Eric van Heck and Otto Koppius

ERS-2006-045-LIS

* A complete overview of the ERIM Report Series Research in Management: https://ep.eur.n//handle/1765/1

ERIM Research Programs:

LIS Business Processes, Logistics and Information Systems

ORG Organizing for Performance

MKT Marketing

F\&A Finance and Accounting

STR Strategy and Entrepreneurship 